\title{
Enhancing Local Economic Independency by Issuing Local Government Bond: Comparing Japan and Indonesia
}

\author{
Alen Ermanita' \\ Ministry of National Development Planning/BAPPENAS - Indonesia
}

\begin{abstract}
For more than a decade, Indonesia has been practicing decentralization. During this period, local governments still experience difficulties in generating local revenues to fund their development. Local government bonds (LGBs) are actually one of the finest sources for financing local development. However, until now there is no real practice in issuing local bonds in Indonesia though it is allowed in the existing regulation. There are still many considerations which hindered the realisation of LGB issuance ranging from the rule of mechanism to the local governments' readiness themselves. To gain more insights about the issue, learning from another country (in this case: Japan) on how they manage LGBs effectively and securely will be beneficial. Comparison model between the two countries is chosen to see the regulation and managerial aspects in LGB implementation including the main institution in central level, rules of the game, buyers and purposes. By having this comparison, it is expected that some crucial factors can be looked at, which may then provide us some information on why LGBs are yet to bloom in Indonesia. Moreover, the comparison is expected to provide some basis about the possibility to ease policy adoption for Indonesia in managing LGBs.
\end{abstract}

Key words: local government bond (LGBs), institutions, buyers, rule of games and purposes 


\section{Enhancing Local Economic Independency by Issuing Local Government Bond: Comparing Japan and Indonesia}

\section{Introduction}

\subsection{Background}

Indonesia undertook a major change on its local governance system in 1999, shortly after President Soeharto (who held the presidency since 1968) stepped down in 1998. The central and local government relationship was then shifted from authoritarian centralistic into democratic de-centralistic (Lewis, 2010). Under decentralisation era, significant authorities as well as funding have been delegated to local level. However, this change has not yet inspired improvement in service delivery and infrastructure conditions in many districts. In practice, there are still many barriers in delivering local government's functions optimally. The first barrier would be the high dependency on central government funding. Turner (2006) argues that Local governments are being more dependent on central transfer since decentralisation. Unfortunately, the dominant proportion of these local government budgets (APBD) is allocated for expenditure on salaries rather than capital expenditures. Secondly, the economic activities are not evenly distributed across space; most of them are still concentrated on Java (57.99\%) and Sumatera (23.81\%) (BPS,2014). This condition brings about difficulties for outer islands (outside Java) to increase their economic performance. Thirdly, there are still disparities in infrastructures development, especially between western and eastern parts of Indonesia (Bappenas, 2015). Poor infrastructure in eastern Indonesia certainly influences the local economy, which in turn also influence its contribution to the national economy. More funding for infrastructure development in the region is greatly needed.

Having these backgrounds, local governments still have a long way to be fully independent economically. When local governments with high transfer dependence encounter unexpected financial problems, it may lead to limitation of raising additional revenues. Thus, their options to cope with the problems will be limited to either cutting services, running deficits, or relying on arrears to employees and contractors (Rodden, 2002). Then, it becomes important to find an alternative for local governments to improve their economic performance particularly on how they finance their infrastructure. In many countries, Mochida (2008) argued that local borrowing is an important source for long term development project.

Local bond policy in Indonesia has not been implemented easily; even when the regulation already allows the local government to issue bonds. There are still many things to be prepared by the central government before local bonds are issued. Some issues need to be well prepared, ranging from local governments' capacity to the rules of mechanism. The following are the factors which hamper local government in issuing LGBs: 1) a local government must obtain the local parliament's approval for issuing each LGB; 2 ) a local government must gain audit rating 'WTP' or satisfactory and 3) macroeconomic stability. In this case, MOF concerns whether both central and local governments are ready to have guarantee mechanism if risks like default or bankruptcy happen (Qorib, 2014).

In order to find the appropriate model, learning from other countries experience could be beneficial. Turning the attention to Japan, this country has the experience in using local bond as an instrument to tackle their local financial problems. Japanese local debt is also remarkably high. For comparison, in FY 2005, general government 
outstanding debt amounted to about JPY 760 Trillion and about JPY 170 trillion was local government debts (New York Times, 2007, in Mochida, 2008). Even though Japan's journey in performing local bond has not always been successful, they have run continuous policy improvement. Japan's local bond system has now gradually shifted from the traditional model (strict administrative control) towards fiscal rule and market discipline (Mochida, 2008). Thus, it is important to learn the experiences as well as the policies on how Japan manages this, and making comparison with Indonesia's case. This study would identify the differences between the two countries as well as the key factors which might lead to policy success (or failure) on local debt. The comparison is also expected to bring some recommendations for the possibility of policy adoption by looking at the compared main aspects in the analysis.

This paper will be divided into five sections. First, the introduction discusses briefly about the condition of decentralisation particularly on fiscal issues between Indonesia and Japan. The second section is the objectives of this paper. The third section contains literature review which mainly discuss about the local government bond and the global system of local finance in Japan. The fourth section compares local bond management between Indonesia and Japan by focusing on several aspects like involved institutions in central level; the rules - mechanism; buyers and purposes. The last section will provide conclusion and recommendation.

\subsection{Objectives}

The following are the objectives of this paper:

- Learning about Japan's local finance system particularly local government bond management

- Conducting comparison of local government bond (LGB) policy between Japan and Indonesia by focusing on several aspects, which are: institutions, rule of game, buyers and purpose

- Proposing recommendations for policy adoption and/or policy adjustment

\section{Literature Review}

\subsection{Local Government Bond (LGB)}

By definition, local government bond could 'represent a promise by state or local government units (called the issuers) or other qualified issuers to repay to lenders (investors) an amount of money borrowed, called principal, along with interest according to a fixed schedule' (O'Hara, 2012, p.1). In Japan, local government bond (LGB) has taken significant role in filling the gap between local fiscal capacity and its development needs. Apart from covering expenditures, LGB also constitute the debt of local government and it is separated from central government debt (MOF, 2014). As an instrument to fill the gap, the areas in which Japan LGB could finance are also limited for: 1) expenditure of public enterprises (traffic, gas, water provision, etc.); 2) investment, loans; 3) re-finance of local bonds; 4) disaster restoration and 5) public works (MIC, 2007). These areas are strictly stipulated in Article 5 of the Local Public Finance Law.

Japan has three different kinds of LGB: 1) individual LGB, which means every local government (prefecture or municipality) may issue bond to the public. Terms and conditions for this LGB are mainly based on the negotiation with syndicated underwriters and bidding process; 2) Joint-LGB, which means more than one local government units sell a certain bond together. Since FY2003, local governments in Japan started offering Joint-LGBs in order to minimize costs and achieve stable financing; and 3) LGB for resident, or called as citizen participatory-type public offering LGB. This instrument aims not only to increase the variation of financing methods for individual investors, but also to urge citizens' participation in local government finance (MIC, 2007). 
In order to prevent the unwanted impact of LGBs issuance, some safeguarding policies must be provided. According to Ter-Minassian and Craig (1997), there are at least four main instruments related to local borrowing which should be opted by the government as an LGB's operating mechanism. The first is high reliance on capital market. In this case, government has fewer roles in managing LGB and let the market takes major part. The second is enforcing strict administrative controls. Local government has to obtain an approval from central before issuing LGB. The third is setting the fiscal rules. The central government might define absolute level of several things like debt service ratio, debt repayment, tax collection ratio and/or net revenue. The fourth is applying cooperative approach or negotiation. However, in the last few years, Japan was in a transition period where implicit government guarantee and strict administrative control have been being phased out in favour of fiscal rules and market discipline (MIC, 2007). During this period, Mochida (2008) argued that a set of actions in performing Japan LGB reform has been developed in recent years for local government advancement in terms of autonomy and selfresponsibility.

Applying similar standing rules of defining limit and/or ratio in LGBs (like Japan) have also been carried out in other countries. Austria and Spain set limits on the absolute level. Germany also arranges the limits of LGB for investment purpose. Yet other countries like Brazil and Korea have applied the same rules like Japan by setting the limit of local debt to their debt service on the revenues (Ter-Minassian and Craig, 1997; Singh and Plekhanov, 2005, in Mochida, 2008, p.137).

\subsection{The Global System of Local Finance in Japan}

During post-war period, local financial system in Japan was significantly changed from highly centralised to more decentralised way. This alteration was initiated by Professor Carl Shoup and was aimed to reduce the dominance of the central government. Because of having more delegated functions, Shoup recommended that local governments should also have other important substances such as increasing tax revenues, applying conditional grants, clear distribution of functions and using equalisation grant (Mochida, 2008). However, in practice, local government finance until now is still closely related with the central government. Not only that local government still tend to rely on central transfers, the central government also constructs Local Fiscal Plan annually alongside the national budget (Park, 2011). Moreover, according to Japan's Local Finance Law, local government finance should be financially independent, while in reality, the central government takes a major role in controlling local budgets (Ishii and Wada, 2015).

Due to the larger responsibilities, local governments in Japan have been equipped with several revenue channels. There are two types of revenue resources: ordinary/common and special revenues. The ordinary revenues include local tax revenues (Chihozei), unconditional tax grants from the central government (ChihoKofuzei), and local shared taxes (Joyo zei). Besides that, special revenues consist of conditional tax grants from the central government (Kokko-Shisyutsu-kin), profits from public sector enterprises, and local government bonds (Ishii and Wada, 2015). Following is the local government revenues breakdown in fiscal year 2012: 
Chart 1. Local Government Revenue Breakdown
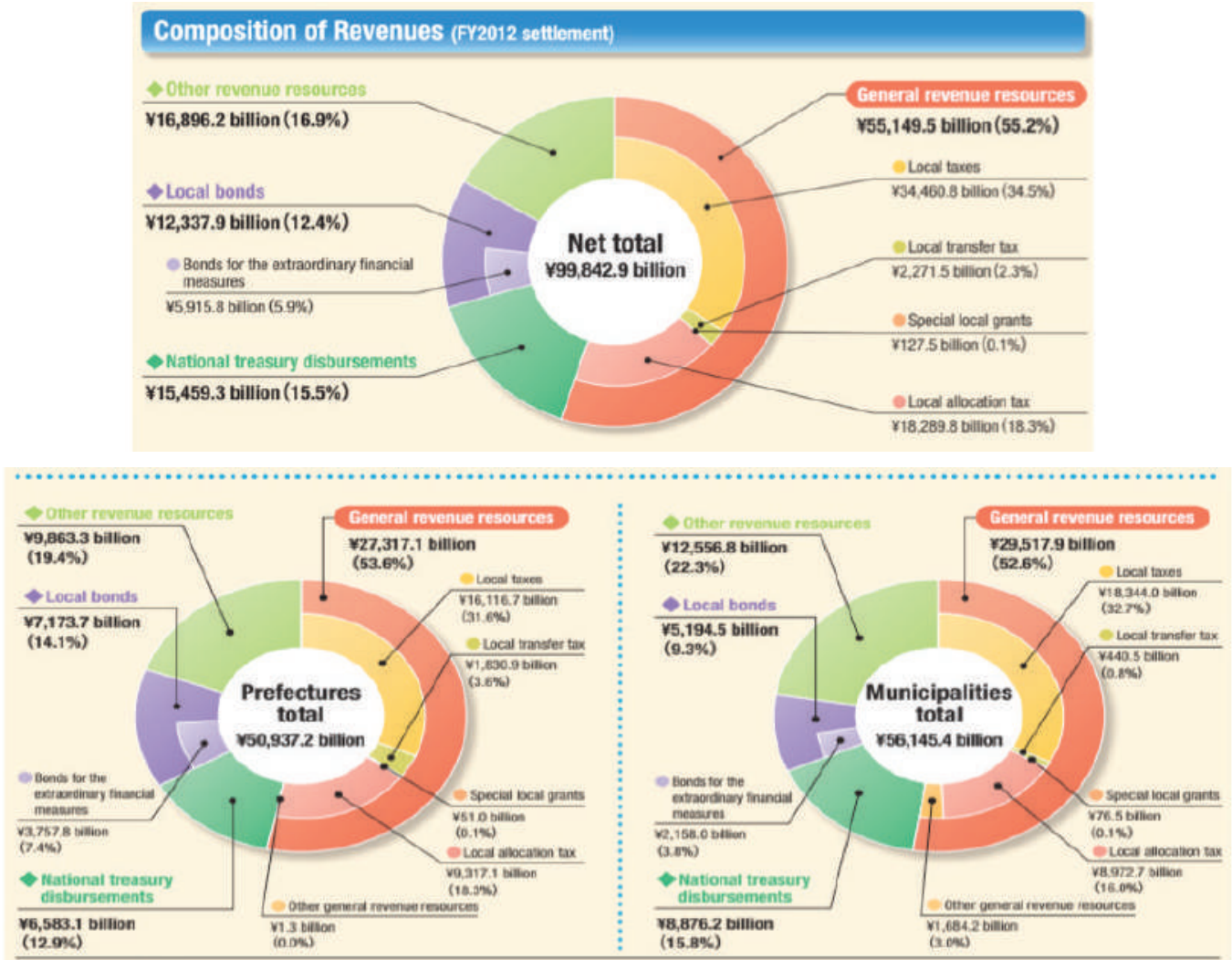

Source: Ministry of Internal Affairs and Communications. White Paper on Local Public Finance, 2014

According to chart 1, the revenue pattern in both prefecture and municipality is quite similar. Their revenues are dominantly derived from local taxes, followed by other revenue resources, such as local allocation taxes (LAT), national treasury disbursement, local government bonds and others. To define such figures, the Ministry of Internal Affairs and Communications (MIC) is mainly responsible to estimate the projected revenues and projected expenditures together with the Ministry of Finance (MOF). Both ministries negotiate and decide what instruments should be selected to fill the gaps (MIC, 2007). Following are the instruments: 1) simply transfer funds from the central in form of various subsidies; 2 ) local allocation taxes (LAT) which are collected nationally but then redistributed to local governments; and 3) if both instruments are insufficient, MOF and MIC must renegotiate and find other means to fill the gap (Park, 2011). One of the means which may be opted is local government bond.

\section{Comparing Japan and Indonesia: Local Government Bond (LGB) Management}

In developing countries, local government bond (LGB) market is highly considered as a competitive alternative besides bank loan (Liu, 2009). Linking with the principle of local autonomy, the aim of increasing local financial independence through local bond issuance seems important. However, it might create significant problems in terms of concept and operational issues, particularly for third world countries with high level of corruption and inequality (Rodden, 2002). 
Therefore, learning good experiences by different countries is worthwhile in identifying the possible problems and may even finding solution and possibilities of policy adoption. In this section, comparison between two countries in LGB management will be analysed into four aspects: involved institutions in the central level, rule of game or mechanism, buyers and purposes.

\subsection{Main Institutions in Central Level}

There are many actors in local government bond market in which each has distinct roles. There are central government (certain ministries), local government, public finance investment bankers, underwriters, salespeople, trader, analysts, lawyers, financial analysts, rating agencies, insurers, commercial bankers, investors, brokers, technology developers and vendors, the media, and regulators (O'Hara, 2012). However, in practice, following are the main actors related to the implementation of local government bond both in Japan and Indonesia:

\begin{tabular}{|c|c|}
\hline Japan & Indonesia \\
\hline $\begin{array}{l}\text { Main Actors: } \\
\text { - Ministry of Internal Affairs and } \\
\text { Communications (MIC) - dominant } \\
\text { - Ministry of Finance (MOF) }\end{array}$ & $\begin{array}{l}\text { Main actors: } \\
\text { - Ministry of Finance - dominant } \\
\text { - Otorita Jasa Keuangan / Financial } \\
\text { Service Authority } \\
\text { - Ministry of Home Affairs }\end{array}$ \\
\hline \multicolumn{2}{|l|}{ RESPONSINILITIES } \\
\hline $\begin{array}{l}\text { Ministry of Internal Affairs and } \\
\text { Communications (MIC) } \\
\text { - monitoring the fiscal situation of each } \\
\text { local government (prefecture and } \\
\text { municipality) } \\
\text { - disallow any local governments } \\
\text { whose debt ratio exceed a defined } \\
\text { limit to issue the bond } \\
\text { - responsible to set certain limits/ratios } \\
\text { for LCBs requirement (Mochida, 2008) }\end{array}$ & $\begin{array}{l}\text { Ministry of Finance (MOF) } \\
\text { 1. giving either approval or refusal for } \\
\text { every LGB issuance } \\
\text { 2. Defining several limits and/or ratios, } \\
\text { such as (GR No. } 30 / 2011) \text { : } \\
\text { - Fiscal capacity for each province } \\
\text { and/or municipal } \\
\text { - Real borrowing necessity of local } \\
\text { government } \\
\text { - Debt service coverage ratio (ratio } \\
\text { which indicates the capacity of } \\
\text { local government to repay the } \\
\text { principal of bond) } \\
\text { - maximum limit of local debt }\end{array}$ \\
\hline \multirow[t]{2}{*}{$\begin{array}{l}\text { Ministry of Finance } \\
\text { - responsible for budget formulation in } \\
\text { - central level } \\
\text { (Nearses the expenaiture process } \\
\text { - maintaining the interest rate of local } \\
\text { bond } \\
\text { - creating solutions to absorb larger } \\
\text { government bond } \\
\text { - In the process of granting the } \\
\text { consent, MIC should coordinate with } \\
\text { MOF in advance }\end{array}$} & $\begin{array}{l}\text { Otoritas Jasa Keuangan / Financial } \\
\text { Service Authority } \\
\text { Responsıbıe to give the errective } \\
\text { declaration for allowing certain LCB to } \\
\text { be issued publicly in the capital market } \\
\text { (Bappenas, 2014). }\end{array}$ \\
\hline & $\begin{array}{l}\text { Ministry of Home Affairs } \\
\text { Although the final decision of LGB's } \\
\text { issuance is within the authority of } \\
\text { MOF, every local government should } \\
\text { consult with MOHA (GR No.30/2011). }\end{array}$ \\
\hline
\end{tabular}


The figure below shows the detail mechanism of LGB issuance in Japan.

Figure 1. LGB Issuance Process in Japan

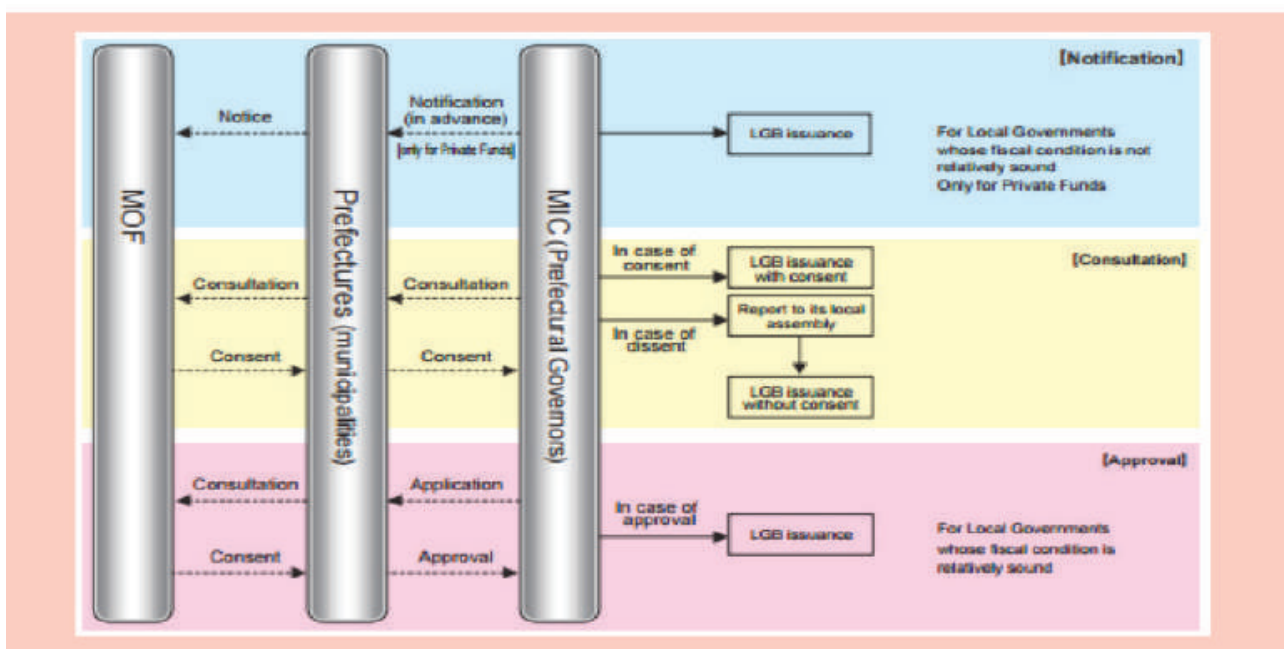

Source: MOF- Japan, 2014

In general, the procedures of LGB issuance in Indonesia must follow several steps (PMK No. 111/2012):

- Defining activities and/or project which will be funded from LGB

- Preparing the feasibility study

- Obtaining the consent of Local Parliament (DPRD)

- Submit all the documents required as mentioned above to the MOF. Afterwards, LGB should be reviewed by OJK

- $\quad$ Preparing the Local Regulation (called Perda)

- If the LGB is approved by MOF and OJK, public offering can be initially started in capital market

\subsection{Rule of the Game}

LGB system in Japan has altered gradually from strict administrative control towards market discipline combined with fiscal rule (Mochida, 2008). Before FY 2006, local government must have approval from MIC for every LGB issuance. This approval system was then abolished, though in particular conditions some local governments still require clearance from central government (MIC, 2007). On the other hand, even though there has been no real implementation yet in Indonesia, the central government has stipulated the mechanism of LGB issuance in GR No. 30/2011 on Local Borrowing. Different with Japan, Indonesia combines the LGB system between strict administrative control and fiscal rules (GR No. 30/2011).

\begin{tabular}{|c|c|}
\hline Japan & Indonesia \\
\hline $\begin{array}{l}\text { Assured by government (MIC, 2007) } \\
\text { - If the gap between needs and revenues i } \\
\text { less than certain limit or in minus } \\
\text { position, central government will decide } \\
\text { necessary action or measurement } \\
\text { - In micro level, local government finance } \\
\text { is also supported by Local Allocation Tax } \\
\text { (LAT) system which is used as reserve } \\
\text { funds }\end{array}$ & $\begin{array}{l}\text { Administrative Control } \\
\text { Each new application of LGB } \\
\text { issuance requires an approval from } \\
\text { MOF, OJK as well as the Local } \\
\text { Parliament (DPRD). } \\
\text { (PMK No.111 Year 2012) }\end{array}$ \\
\hline
\end{tabular}




\begin{tabular}{|c|c|}
\hline & $\begin{array}{l}\text { Getting DPRD's approval being } \\
\text { one of the crucial factors which } \\
\text { hindered the realisation of LCB's } \\
\text { issuance. It seems difficult to mix } \\
\text { between government's purpose } \\
\text { and politician's interest. This } \\
\text { situation resulted in some LGB } \\
\text { proposals cannot be processed } \\
\text { until now such as DKI Jakarta and } \\
\text { Bandung. }\end{array}$ \\
\hline $\begin{array}{l}\text { Early warning system } \\
\text { Even though the approval system of } \\
\text { LGBs was abolished and the new } \\
\text { "inform and consult" system started, the } \\
\text { central government still has an 'early } \\
\text { warning system'. } \\
\text { In detail, the following are the } \\
\text { arrangements for each limit (MIC, 2007; } \\
\text { MOF, 2014): } \\
\text { - Debt Payments Ratio in General } \\
\text { Accounts For local governments whose } \\
\text { debt payments are over } 18 \% \text { of its total } \\
\text { general revenues, an approval rrom MIC } \\
\text { must be obtained } \\
\text { - Deficit Level in General Accounts } \\
\text { If a local government touches the } \\
\text { maximum level of deficit, approval from } \\
\text { MIC is needed (2.5\% for Prefectures and } \\
\text { Designated Cities to 10\%) } \\
\text { approval system of MIC is also required } \\
\text { for particular conditions related to the } \\
\text { delay of interest or redemption } \\
\text { payment }\end{array}$ & $\begin{array}{l}\text { Fiscal Rule } \\
\text { Every local government should apply } \\
\text { all of these limits below before } \\
\text { submitting their LGB (PMK No. } \\
\text { 111/2O12; CR No 30/2011): } \\
\text { - the total of debt outstanding (new } \\
\text { debt and existing debt) cannot } \\
\text { exceed } 75 \% \text { of total local } \\
\text { government revenues in the } \\
\text { previous fiscal year } \\
\text { - Audit rating must be "WTP" (Wajar } \\
\text { Tanpa Pengecualian) or at least } \\
\text { "WDP" (Wajar dengan } \\
\text { Pengecualian). This audit rating is } \\
\text { commonly known as 'high } \\
\text { satistactory leveI. Oniy rew } \\
\text { number of local government gain } \\
\text { this 'WTP' rating. In some degree, } \\
\text { it limits the opportunity for other } \\
\text { local governments to propose } \\
\text { LCBs. } \\
\text { - its DSCR (debt service coverage } \\
\text { ratio) cannot exceed } 2.5 \text { every } \\
\text { single year } \\
\text { - maximum limit of cumulative } \\
\text { deficit in APBN and APBD is } 3 \% \text { of } \\
\text { current CDP }\end{array}$ \\
\hline $\begin{array}{l}\text { Fiscal reconstruction plan } \\
\text { - Formulating new comprehensive index } \\
\text { as a tool to monitor financial position of } \\
\text { local government } \\
\text { - Involving both central and prefecture in } \\
\text { reconstruction planning } \\
\text { - Executing temporary financing of } \\
\text { deficit related to LCB (MIC, } 2006 \mathrm{~d} \text {, in } \\
\text { Mochida, 2008, 130). }\end{array}$ & $\begin{array}{l}\text { No Central Guarantee } \\
\text { There are no any guarantee from } \\
\text { central government if LCB } \\
\text { experience the unwanted problem } \\
\text { such as default. The certain } \\
\text { scheme should be obeyed by the } \\
\text { local government to minimize this } \\
\text { risk (Bappenas, 2014; PMK No. } \\
111 / 2012 \text { ): } \\
\text { - Providing Reserve Funds } \\
\text { - Assigning a specific institution } \\
\text { (guarantor) which is responsible to } \\
\text { assure each LCB can be absorbed in } \\
\text { the capital market. } \\
\text { - Local government should hire some } \\
\text { professionals to manage bonds in } \\
\text { the capital market. }\end{array}$ \\
\hline
\end{tabular}




\begin{tabular}{|l|l|} 
& $\begin{array}{l}\text { This ruling mechanism might lead } \\
\text { to the low participation of local } \\
\text { government in proposing LGBs to } \\
\text { the central government. In this } \\
\text { scheme, all of burdens if the worst } \\
\text { case happen is on the local } \\
\text { government's side. }\end{array}$ \\
\hline $\begin{array}{l}\text { Market Discipline } \\
\text { Releasing LGBs to the market should be } \\
\text { equipped with some preconditions such as } \\
\text { (Ter-Minasian and Craig, 1997): } \\
\text { - adequate information about borrower's } \\
\text { capacity to the creditors; } \\
\text { - regulations on financial } \\
\text { no intermediaries } \\
\text { bailout seems irrational } \\
\text { - local government must monitor and } \\
\text { respond to market signals before } \\
\text { deciding to issue new borrowing or not }\end{array}$ & \\
\hline
\end{tabular}

\subsection{Buyers or Funding Sources}

\begin{tabular}{|c|c|}
\hline Japan & Indonesia \\
\hline $\begin{array}{l}\text { 1. LCBs in Japan can be funded into two } \\
\text { main sources: } \\
\text { - Public funds which are derived from } \\
\text { the Fiscal Loan Funds and the Japan } \\
\text { Finance Organization for for } \\
\text { Municipalities Funds }{ }^{2} \text {. (Park, 2011; } \\
\text { MOF, 2014). } \\
\text { - Private funds cover public offering } \\
\text { funds and private placement funds. } \\
\text { (MOF, 2014) } \\
\text { 2. In general, the buyers of these LGBs } \\
\text { are central government through FILP, } \\
\text { particular institutions in central level, } \\
\text { citizens and private sector (Park, 2011; } \\
\text { MOF, 2014). } \\
\text { 3. Japan has no restriction for foreign } \\
\text { residents and/or companies who } \\
\text { intend to involve in purchasing LCBs } \\
\text { (Park, 2011; MOF, 2014) }\end{array}$ & $\begin{array}{l}\text { LGBs in Indonesia are publicly } \\
\text { offered in the capital market. Thus, } \\
\text { every party can purchase LGBs } \\
\text { either derived from: public } \\
\text { institutions, private organisations or } \\
\text { individual residents. }\end{array}$ \\
\hline
\end{tabular}

Based on the budget figure in FY 2014 (see Figure 2 below), LGBs in Japan are mainly funded by private funds derived from public offerings and private placement funds, then followed by public funds. This trend of creditor's contribution has been predicted to change from public funds to private funds (Mochida, 2008).

\footnotetext{
2 The Fiscal Loan Funds are included in the Fiscal Investment and Loan Program (FILP) provided by the central government as a funding source of LGB. The Japan Finance Organization for Municipalities Funds is funded by investment from all regions to assist local governments in financing long term and low-interest rate of LGBs

3 Public offering here means that local governments will purchase their bonds through markets. In addition, private placement funds are LGBs which are purchased by financial institutions and some business associations.
} 
Figure 2.

\section{Local Government Bonds (LGB)}

(1) Overview of LGB Program in FY2014

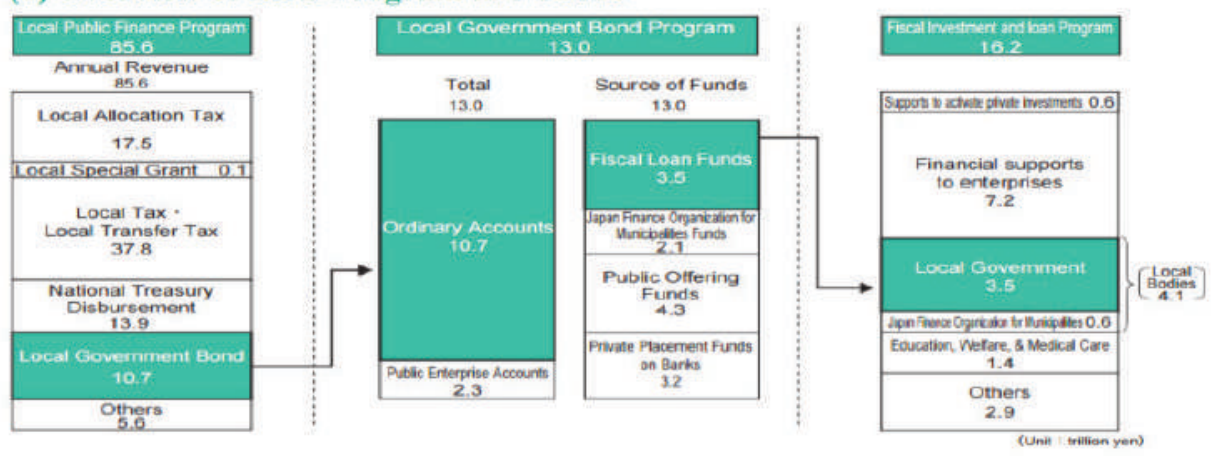

Source: MOF- Japan, 2014

\subsection{Purposes}

\begin{tabular}{|l|l|}
\hline Japan & Indonesia \\
\hline $\begin{array}{l}\text { The areas in which local bonds can be } \\
\text { issued are clearly stipulated into } \\
\text { several parts (MIC, 2007): }\end{array}$ & $\begin{array}{l}\text { The objectives of LCB issuance in } \\
\text { Indonesia are not specifically defined } \\
\text { in the existing regulation. }\end{array}$ \\
$\begin{array}{l}\text { Based on the respective regulation, } \\
\text { Expenditure of public enterprises like } \\
\text { traffic, gas, water provision; }\end{array}$ & $\begin{array}{l}\text { LCB can be issued to finance any kinds } \\
\text { of public service infrastructures which } \\
\text { have the potential to generate revenue } \\
\text { Investment, loans; }\end{array}$ \\
$\begin{array}{l}\text { Re-finance of local bonds; } \\
\text { - Disaster restoration; }\end{array}$ & \\
\hline Public works & \\
\hline
\end{tabular}

\section{Conclusion and Recommendation}

\subsection{Conclusion}

The comparison between Indonesia and Japan revealed a number of important points in understanding the current situations of the two countries, their strengths and weaknesses, and the challenges they face. After reviewing the main aspects which have been compared in both countries (actors, rule of game, purposes and buyers), policy adoption might not be simple for Indonesia's case. We can see some of the conditions is quite different, and significantly so, particularly in the rule of the game. The absent of safeguarding mechanism from the central Government, and the lack obligation to qualify for WTP seem to be a factor that hinders LGB proposal for local governments. Considering the lack of reference in this particular issue, so further research to look more into the matter is highly needed.

To summarise, the following are the main aspects in this paper which need to be considered before applying the full implementation of LGB in Indonesia:

- Main actors: applying separated functions between issuer, operator and checker in respective local government 
- Rule of game: Safeguard policy seems important to be applied. It considers that not all local governments have back up plan if unwanted things in LGB's management happen (such as default)

- Purpose: Indonesia needs to be more focus on the LGB's purposes itself.

- Buyers: LGBs can be purchased by everyone but it seems crucial to have the arrangement of portfolio investment

\subsection{Recommendation}

If Indonesia wants to adopt several concepts or mechanism in Japan's LGB, there are some key factors that Indonesia needs to consider (Liu, 2009):

1. Macroeconomic stability. Issuing LGBs is not only an intergovernmental fiscal relationship between central and local but it also engages other parties such as creditors. Therefore, assuring overall economic stability is crucial to attract the buyers and maintaining their trust level.

2. Ex-Ante Regulatory Frameworks. There are several suggestions which might be useful to be considered as a pre-implementation of LGBs:

- Central government needs to provide effective fiscal rules (setting the limits and/or ratios). Due to high reliance of local finance on central transfer, applying strict fiscal rules before issuing bonds seems reasonable in preventing the potential of negative impacts of LGBs.

- Enforcing the local government's transparency such as involving independent audit, periodic public disclosure of key fiscal data, and others.

- The purposes of issuing LGBs should be also clearly define to ensure that local government would spend bond wisely and effectively

- Revising the condition related to the collateral aspect in the existing regulation. In this case, if the projects/assets funded by LGBs are inadequate to be categorised as collateral, central should rethinking about another formula to ensure that local government is able to provide sufficient reserve funds.

3. Ex-Post Insolvency System. The vertical imbalance as well as high reliance on central transfer among local government in Indonesia is still high. Central government should at least think about the safeguard policy for LGBs management 


\section{References}

Badan Perencanaan Pembangunan Nasional (2014). Laporan Kajian Tinjauan Regulasi dan Kelembagaan Penerbitan Obligasi Daerah Dalam Pembangunan Infrastruktur Di Daerah. Jakarta: Bappenas.

Badan Perencanaan Pembangunan Nasional (2015). Rencana Pembangunan Jangka Menengah 2015-2019. Jakarta: Bappenas.

Government Regulation (GR) Number 30 Year 2011 about Local Borrowing. Jakarta: The Government of Republic Indonesia

Ishii, H. and Wada, E. (2015). Working Papers Local Government Spending: Solving the Mystery of Japanese Fiscal Packages. Massachusetts: Peter G. Peterson Institute for International Economics.

Lewis, B.D. (2010) 'Indonesian Decentralization: Accountability Deferred', International Journal of Public Administration, 33 (12), p.648-657, DOI: 10.1080/01900692.2010.514442.

Liu, L. (2009). 'Subnational Borrowing and Debt Management', Presented in Ministry of Finance Workshop, Jakarta, 10 June 2009.

Mochida, N. (2008). Fiscal Decentralisation and Local Public Finance in Japan. Oxon: Routledge.

Ministry Of Finance (2014). White Paper on Local Public Finance. Japan: MOF.

Ministry of Internal Affairs and Communication (2007). Local Government Finance System \& Local Government Bond Market in Japan, presented in Japan, 17 April 2007.

Neary, I. (2006). The State and Politics in Japan. Cambridge: Polity Press.

O'Hara, N. (2012). The Fundamentals of Municipal Bonds. New Jersey: John Wiley \& Sons, Inc.

Park, G.(2011). Spending Without Taxation: FILP and the Politics of Public Finance in Japan. Stanford, CA: Stanford University Press.

Peraturan Menteri Keuangan (PMK) No. 111 Year 2012 about The Issuance and Accountability Procedures of Local Bond. Jakarta: Ministry of Finance

Public Finance Division, Local Government of Hachioji, 2015.

Qorib, Fathan. (2014). Ini penyebab Pemda sulit terbitkan obligasi, 20 Maret 2014. Hukumonline.com. Halaman ini diakses pada tanggal 22 September 2017, pukul 17:00 wib.

Rodden, J.A. (2002). 'The Dilemma of Fiscal Federalism: Grants and Fiscal Performance around the World', American Journal of Political Science, 46 (3), p. 670-687.

Ter-Minasian, T and Craig, J. (1997). "Control of Subnational Government Borrowing", in Ter- Minasian, T. (1997) (ed) Fiscal Federalism in Theory and Practice. Washington DC: IMF.

Turner, M. (2006). 'From commitment to consequences', Public Management Review, 8 (2), p.253-272, DOI: 10.1080/14719030600587471. 